\title{
Ixodes tropicalis (Acari: Ixodidae) infesting a human and molecular detection of Rickettsia bellii, Colombia
}

Juan C. Quintero', María L. Félix², José M. Venzal'2, Santiago Nava ${ }^{3}$

${ }^{1}$ Grupo de Investigación en Ciencias Veterinarias, Centauro, Facultad de Ciencias Agrarias, Universidad de Antioquia, Medellín, Colombia

${ }^{2}$ Laboratorio de Vectores y Enfermedades Transmitidas, Facultad de Veterinaria, Centro Universitario Regional Litoral Norte, Universidad de la República del Uruguay, Salto, Uruguay

${ }^{3}$ Instituto Nacional de Tecnología Agropecuaria, Estación Experimental Agropecuaria Rafaela, Santa Fe, Argentina

Introduction: Ixodes tropicalis is a little-known tick species reported parasitizing wild rodents only in Colombia and Perú.

Objective: To report a case of I. tropicalis infesting a human in the south of the metropolitan area of the Valle de Aburrá, Antioquia, Colombia, and to report the molecular detection of Rickettsia bellii in this species.

Materials and methods: The tick was identified using a morphological key and sequencing of tick mitochondrial 16S rRNA. Additionally, bacterial and protozoa pathogens were evaluated using PCR for the detection of Rickettsia spp., family Anaplasmataceae, Borrelia spp., and piroplasmid.

Results: We identified the tick as an I. tropicalis female according to Kohls, 1956, description and to partial 16S rRNA sequences showing a minimum of $5 \%$ divergencies compared to Ixodes sequences. We also detected the gltA gene of $R$. bellii in the tick with $99.87 \%$ of identity.

Conclusion: This is the first report in Colombia of a species of the Ixodes genus parasitizing a human and the first report of the detection of $R$. bellii in this tick species.

Keywords: Ixodes; Rickettsia; bacteria; disease vectors.

Infestación de Ixodes tropicalis (Acari: Ixodidae) en un humano y detección molecular de Rickettsia bellii, Colombia

Introducción. Ixodes tropicalis es una especie de garrapata poco conocida que se había reportado parasitando únicamente roedores silvestres en Colombia y Perú.

Objetivo. Reportar un caso de infestación por I. tropicalis en un ser humano del sur del área metropolitana del Valle de Aburrá (Antioquia) y reportar la detección molecular de Rickettsia bellii en esta especie.

Materiales y métodos. La garrapata se identificó usando claves morfológicas y mediante la secuenciación de su gen 16S ARNr mitocondrial. Además, se evaluó la presencia de

Received: 07/05/2020 Accepted: $10 / 08 / 2020$

Published: 29/10/2020

\section{Citation:}

Quintero JC, Félix ML, Venzal JM, Nava S. Ixodes tropicalis (Acari: Ixodidae) infesting a human and molecular detection of Rickettsia bellii, Colombia. Biomédica. 2021;41:347-52.

https://doi.org/10.7705/biomedica.5464

\section{Corresponding author:}

Juan Carlos Quintero, Grupo Ciencias Veterinarias Centauro, Facultad de Ciencias Agrarias, Universidad de Antioquia, Sede de Investigación Universitaria, Torre 2, Laboratorio 233, Medellín, Colombia Teléfono: (323) 2302447

juan.quintero@udea.edu.co

\section{Author contributions:}

All authors participated in the conceptualization, data curation, investigation, methodology, validation, visualization, and writing of the manuscript.

Funding:

This study received no funding.

Conflicts of interest:

The authors declare no financial or personal conflicts of interest regarding this report. agentes patógenos bacterianos y protozoos usando PCR para la detección de Rickettsia spp., la familia Anaplasmataceae, Borrelia spp. y piroplásmidos.

Resultados. La garrapata se identificó como una hembra de I. tropicalis, según la descripción de Kohls, 1956, y la secuencia parcial del gen 16S ARNr, la cual mostró una divergencia de mínimo $5 \%$ en la comparación con las secuencias de Ixodes. Además, se detectó el gen gltA de $R$. bellii en esta garrapata con una similitud del 99,87\%.

Conclusión. Este es el primer reporte en Colombia de una especie del género Ixodes parasitando a un humano y el primer reporte de la detección de $R$. bellii en esta especie de garrapata.

Palabras clave: Ixodes; Rickettsia; bacterias; vectores de enfermedades.

Ticks are non-permanent ectoparasites with a worldwide distribution. With some exceptions, they are obligate hematophagous in both immature and adult stages that infest a great diversity of hosts including amphibians, reptiles, birds, and mammals (1). About 950 tick species have been recognized and are included in three families: Agasidae, Nuttalliellidae, and Ixodidae (2-4). Ticks are able to transmit bacteria (spirochetes and rickettsiae), protozoans, viruses, and nematodes, making them one of the most important vectors of pathogenic agents in public and veterinary health (5). Hard ticks of the Ixodidae family are also the host species of Rickettsia spp. of unknown pathogenicity such as Rickettsia bellii (6). This species has been detected in several species of Amblyomma and Ixodes genera (7-10). 
Ixodes tropicalis Kohls, 1956, was described from females collected from the wild rodents Thomasomys nicefori (as Thomasomys aureus) in Valdivia (Antioquia), and from Dactylomys boliviensis in San Juan, Tambopata, Sandia (Puno, Perú) (11). Later, immature ticks determined as I. tropicalis were reported infesting another wild rodent, Nephelomys childi (as Oryzomys albigularis), in the Valle de Pichindé (Valle del Cauca), and the Pichindé virus was isolated from them (12). However, this report of I. tropicalis should be considered doubtful because its larvae and nymph have not been formally described (2). Thus, the only bona fide records of $I$. tropicalis correspond to those of the original description (11).

This study aims to report a case of $I$. tropicalis infesting a human, as well as the molecular detection of $R$. bellii in the south of the metropolitan area of Valle de Aburrá (Antioquia).

\section{Materials and methods}

On March 18, 2018, a 59-year-old man was gardening at his house in La Tablaza, La Estrella (Antioquia) (607’02”N, 753'14”W; 1756m). Later, he was found parasitized by a tick in the abdomen umbilical region, which was removed, placed in $96 \%$ ethanol, and sent to Universidad de Antioquia. The classification of the tick was made following the description of Kohls, 1956 (11), with a stereomicroscope (Nikon SMZ1000'TM, Tokyo, Japan).

For molecular studies, the tick was longitudinally bisected using sterile scalpel blades and forceps, rinsed with distilled water to remove ethanol, and crushed with a homogenization pestle. The DNA was extracted using the commercial kit PureLink Genomic DNA Mini Kit'TM (Invitrogen, Germany) following the manufacturer's instructions. DNA was tested by polymerase chain reaction (PCR) targeting the tick mitochondrial 16S rRNA gene (13) and gltA and ompA genes for Rickettsia spp., 16S rRNA gene of the family Anaplasmataceae, flagellin gene of Borrelia spp., and 18S rRNA gene of piroplasmid (14-18).

\section{Results}

The tick (a slightly engorged specimen) was identified as a female of $I$. tropicalis based on the following morphological characteristics: Idiosoma suboval, length from the tip of scapulae to the posterior margin of the body (excluding capitulum) $2.15 \mathrm{~mm}$, width $1.66 \mathrm{~mm}$; scutum, with numerous punctations, length $1.30 \mathrm{~mm}$ and width $1.15 \mathrm{~mm}$; elevated lateral carinas extending from the scapulae to about the mild-length of the scutum; capitulum, porose areas large and semicircular in shape, separated by about the diameter of one, cornua short and rounded, palpal segment two a little longer than segment three, auricula large and posterolaterally directed; hypostome, broken at the base; coxa I of legs with moderately long internal spur and coxae I-IV with a conspicuous external spur; spiracular plate subcircular in shape (figure $1 \mathrm{~A}, \mathrm{~B}$ ).

We amplified fragments of the mitochondrial 16S rRNA gene of the tick and gltA gene of Rickettsia and purified the amplicons using a PureLink Quick PCR Purification Kit ${ }^{\mathrm{TM}}$ (Invitrogen, Germany), which we sent to Macrogen (Seoul, Korea) for sequencing. We did not amplify the DNA of piroplasmid, Borrelia spp., Anaplasmataceae agents, and the ompA gene of Rickettsia. The partial sequence obtained for the 16S rRNA gene of the specimen determined as I. tropicalis (ca. $410 \mathrm{bp}$ ) diverged by more than $5 \%$ when compared to the remaining Ixodes sequences available at the Genbank. 


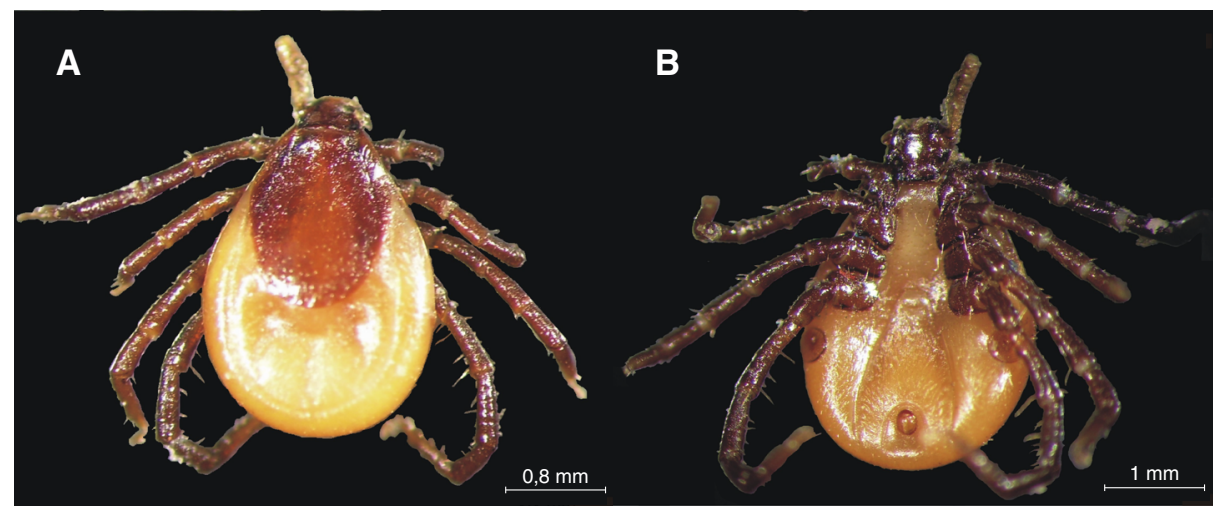

Photography by José Manuel Venzal

Figure 1. Female of Ixodes tropicalis. A. Dorsal view; capitulum, porose areas large, and semicircular in shape. B. Ventral view; hypostome, broken at the base, coxa I with moderately long internal spur, and spiracular plate subcircular in shape. The specimen has been deposited in the "Tick Collection of Instituto Nacional de Tecnología Agropecuaria, Estación Experimental Agropecuaria INTA Rafaela": (INTA2470).

The partial gltA (784 bp) sequence showed $99.87 \%$ (783/784 bp) of identity with the corresponding $R$. bellii sequences (GenBank accession numbers: CP000087, AY375161, U59716). The sequences generated in the study were deposited in the GenBank under the accession numbers MT158325 for the 16S rRNA gene of I. tropicalis and MT174170 for the gltA gene of $R$. bellii.

\section{Discussion}

Besides I. tropicalis, another ten species belonging to the genus Ixodes are currently recognized in Colombia: Ixodes affinis in Carnivora and Artiodactyla (19,20); Ixodes auritulus in Passeriformes (21); Ixodes bocatorensis in Rodentia (22); Ixodes boliviensis in Didelphimorphia and Carnivora $(20,23,24)$; Ixodes montoyanus in Artiodactyla $(25,26)$; Ixodes lasallei in Rodentia (22,26,27); Ixodes luciae in Didelphimorphia (28); Ixodes pararicinus in Artiodactyla $(19,29)$; Ixodes tapirus in Perissodactyla (11), and Ixodes venezuelensis in Rodentia (30). The records of Ixodes fuscipes (31) and Ixodes brunneus (23) for Colombia are currently considered not valid because the taxonomic status of the specimens assigned to these taxa is undetermined $(32,33)$.

Most of these species do not infest humans. Only I. boliviensis, I. brunneus, and I. pararicinus were ocasionally found infesting humans (34). For Colombia, ten species of hard ticks have been reported parasitizing humans (34-37): Amblyomma dissimile, A. mixtum, A. oblongoguttatum, A. ovale, A. patinoi, A. sabanerae, Dermacentor imitans, D. nitens, Rhipicephalus microplus, and $R$. sanguineus sensu lato. Therefore, this finding corresponds to the first report of the genus Ixodes parasitizing humans in Colombia, as well as the first record for I. tropicalis in humans.

Regarding the detection of R. bellii in Colombia, Miranda, et al. (2014), detected it in the free-living larvae of Amblyomma sp. (38) from the northern coast of Colombia (Los Córdobas, Córdoba). In an area near Los Córdobas, $R$. bellii in A. ovale was detected and collected from a donkey in Necoclí (39). Besides, $R$. bellii has been detected in larvae of $A$. dissimile collected in Rhinella horribilis and Basiliscus basiliscus in the department of Magdalena $(40,41)$. 
As far as we know, this is the first report of $I$. tropicalis infesting a human and of $R$. bellii in this species in Colombia, and it would broaden the panorama regarding tick species infesting humans and the exposition to rickettsial agents in the population living in the south of the metropolitan area of the Valle de Aburrá in Antioquia.

These findings demonstrate the presence of I. tropicalis as a potential parasite in humans in the south of the metropolitan area of the Valle de Aburrá Valley, as well as the report on the presence in this tick species of $R$. bellii, a bacteria of unknown pathogenicity in humans. Finally, it is crucial to determine other regions at risk of rickettsial agents' transmission besides those already known such as the Urabá area in Antioquia and the Villeta municipality in the department of Cundinamarca.

\section{Acknowledgments}

We are thankful to Jorge Vélez-Correa for sending the specimen to the Centauro laboratory at Universidad de Antioquia.

\section{References}

1. Hoogstraal H. Argasid and Nuttalliellid ticks as parasites and vectors. Adv Parasit. 1985;24:135-238. https://doi.org/10.1016/s0065-308x(08)60563-1

2. Guglielmone AA, Apanaskevich DA, Estrada-Peña A, Robbins RG, Petney TN, Horak IG. The hard ticks of the world: (Acari: Ixodida: Ixodidae). Springer Netherlands; 2014. p. 1-6, 373523. https://doi.org/10.1007/978-94-007-7497-1

3. Guglielmone A, Sánchez M, Franco L, Nava S, Rueda L, Robbins R. Hard ticks (Acari Ixodida: Ixodidae): A non-profit open-access web portal for original descriptions of tick species (valid and invalid), dubious and uncertain names, and selected nomina nuda. Access: November 17, 2019. Available at: http://rafaela.inta.gob.ar/nombresgarrapatas/. 2015

4. Nava S, Venzal JM, González-Acuña D, Martins T, Guglielmone AA. Ticks of the southern cone of America. Diagnosis, ditricution, and hosts with taxonomy, ecology and sanitary importance. London: Academic Press; 2017. p. 70-8, 117-23, 188-92, 256-62

5. Sonenshine D. Biology of ticks. New York, NY: Oxford University Press; 1991. p. 447.

6. Labruna MB. Ecology of rickettsia in South America. Ann N Y Acad Sci. 2009;1166:156-66 https://doi.org/10.1111/j.1749-6632.2009.04516.x

7. Gillespie JJ, Williams K, Shukla M, Snyder EE, Nordberg EK, Ceraul SM, et al. Rickettsia phylogenomics: Unwinding the intricacies of obligate intracellular life. PLoS ONE. 2008;3:132. https://doi.org/10.1371/journal.pone.0002018

8. Labruna MB, Salim Mattar V, Nava S, Bermúdez S, Venzal JM, Dolz G, et al. Rickettsioses in Latin America, Caribbean, Spain and Portugal. Rev MVZ Córdoba. 2011;16:2435-57.

9. Barbieri ARM, Romero L, Labruna MB. Rickettsia bellii infecting Amblyomma sabanerae ticks in El Salvador. Pathog Glob Health. 2012;106:188-9. https://doi.org/10.1179/2047773212Y.0000000022

10. McIntosh D, Bezerra RA, Luz HR, Faccini JLH, Gaiotto FA, Giné GAF, et al. Detection of Rickettsia bellii and Rickettsia amblyommii in Amblyomma longirostre (Acari: Ixodidae) from Bahia state, Northeast Brazil. Brazilian J Microbiol. 2015;46:879-83. https://doi.org/10.1590/S1517-838246320140623

11. Kohls GM. Eight new species of Ixodes from Central and South America (Acarina: Ixodidae). J Parasitol Arch. 1956;42:613-73.

12. Trapido H, Sanmartín C. Pichindé virus, a new virus of the Tacaribe group from Colombia. Am J Trop Med Hyg. 1971;20:631-41.

13. Mangold AJ, Bargues MD, Mas-Coma S. Mitochondrial $16 \mathrm{~S}$ rDNA sequences and phylogenetic relationships of species of Rhipicephalus and other tick genera among Metastriata (Acari: Ixodidae). Parasitol Res. 1998;84:478-84. https://doi.org/10.1007/s004360050433 
14. Regnery RL, Spruill CL, Plikaytis BD. Genotypic identification of rickettsiae and estimation of intraspecies sequence divergence for portions of two rickettsial genes. J Bacteriol. 1991;173:1576-89. https://doi.org/10.1128/jb.173.5.1576-1589.1991

15. Labruna MB, Whitworth T, Bouyer DH, Mcbride JW, Pinter A, Popov V, et al. Rickettsia species infecting Amblyomma cooperi ticks from an Area in the State of Sao Paulo, Brazil, where Brazilian spotted fever is endemic. J Clin Microbiol. 2004;42:90-8. https://doi.org/10.1128/jcm.42.1.90-98.2004

16. Parola $P$, Inokuma $H$, Camicas J-L, Brouqui $P$, Raoult D. Detection and identification od spotted fever group Rickettsiae and Ehrlichiae in African ticks. Emerg Infect Dis. 2001;7:10147. https://doi.org/10.3201/eid0706.010616

17. Barbour AG, Maupin GO, Teltow GJ, Carter CJ, Piesman J. Identification of an uncultivable Borrelia species in the hard tick Amblyomma americanum: Possible agent of a Lyme disease-like illness. J Infect Dis. 1996;173:403-9. https://doi.org/10.1093/infdis/173.2.403

18. Soares JF, Girotto A, Brandão PE, Da Silva AS, França RT, Lopes ST, et al. Detection and molecular characterization of a canine piroplasm from Brazil. Vet Parasitol. 2011;180:203-8. https://doi.org/10.1016/j.vetpar.2011.03.024

19. Máttar S, Valencia GL. Searching for Lyme disease in Colombia: A preliminary study on the vector. J Med Entomol. 1998;35:324-6. https://doi.org/10.1093/jmedent/35.3.324

20. Acevedo-Guitiérrez L, Paternina L, Pérez-Pérez J, Londoño A, López G, Rodas JD. Garrapatas duras (Acari: Ixodidae) de Colombia, una revisión a su conocimiento en el país. Acta Biol Colomb. 2020;25:126-39.

21. González-Acuña D, Venzal JM, Keirans JE, Robbins RG, Ippi S, Guglielmone AA. New host and locality records for the Ixodes auritulus (Acari: Ixodidae) species group, with a review of host relationships and distribution in the neotropical zoogeographic region. Exp Appl Acarol. 2005;37:147-56. https://doi.org/10.1007/s10493-005-8434-y

22. Apanaskevich DA, Bermúdez SE. Description of a new species of Ixodes Latreille, 1795 (Acari: Ixodidae) and redescription of I. lasallei Méndez \& Ortiz, 1958, parasites of agoutis and pacas (Rodentia: Dasyproctidae, Cuniculidae) in Central and South America. Syst Parasitol. 2017;94:463-75. https://doi.org/10.1007/s11230-017-9718-4

23. Osorno-Mesa E. Las garrapatas de la República de Colombia. Revista de la Facultad Nacional de Agricultura Medellín. 1942;5:57-103.

24. Guglielmone AA, Estrada-Peña A, Keirans JE, Robbins RG. Ticks (Acari: Ixodida: Argasidae, Ixodide) of the neotropical zoogeographic region. Houten, The Netherlands: International Consortium on Ticks Tick-borne Diseases Atalanta; 2003. p. 1-174.

25. Cooley RA. Ixodes montoyanus (Ixodidae) a new tick from Colombia. Bol Sanit Pan Am. 1944;23:804-6.

26. Keirans JE. Ixodes (I.) montoyanus Cooley (Acarina: Ixodidae): First description of the male and immature stages, with records from deer in Colombia and Venezuela. J Med Entomol. 1973;10:249-54. https://doi.org/10.1093/jmedent/10.3.249

27. Méndez-Arocha M, Ortíz I. Revisión de las garrapatas venezolanas del género Ixodes Latreille, 1795 y estudio de un nuevo Amblyomma (Acarina: Ixodidae). Mem Soc Cienc Nat La Salle. 1958;18:196-208.

28. Jones EK, Clifford CM, Keirans JE, Kohls GM. The ticks of Venezuela (Acarina: Ixodoidea) with a key to the species of Amblyomma in the Western Hemisphere. Bull Biol Ser. 1972;17.

29. Keirans JE, Needham GR, Oliver JH. The Ixodes ricinus complex worldwide: Diagnosis of the species in complex, host and distribution. Acarology. 1999;2:341-7.

30. Durden LA, Keirans JE. Description of the larva, diagnosis of the nymph and female based on scanning electron microscopy, hosts, and distribution of Ixodes (Ixodes) venezuelensis. Med Vet Entomol. 1994;8:310-6. https://doi.org/10.1111/j.1365-2915.1994.tb00094.x

31. Neumann LG. Ixodidae. Das Tierreich No. 26. City: Berlin. Editor; Friedländer and Sohn. 1911.

32. Labruna MB, Onofrio VC, Barros-Battesti DM, Gianizella SL, Venzal JM, Guglielmone AA. Synonymy of Ixodes aragaoi with Ixodes fuscipes, and reinstatement of Ixodes spinosus (Acari: Ixodidae). Ticks Tick Borne Dis. 2020;11:101349.

https://doi.org/10.1016/j.ttbdis.2019.101349 
33. Bottero MN, Beati L, Venzal JM, Guardia L, Thompson CS, Mangold AJ, et al. Ixodes silvanus n. sp. (Acari: Ixodidae), a new member of the subgenus Trichotoixodes Reznik, 1961 from northwestern Argentina. Ticks Tick Borne Dis. 2021;12:101572.

https://doi.org/10.1016/j.ttbdis.2020.101572

34. Guglielmone AA, Robbins RG. Hard ticks (Acari: Ixodida: Ixodidae) parasitizing humans. Dordrecht, The Netherlands: Springer International Publishing; 2018. p. 1-210. https://doi.org/10.1007/978-3-319-95552-0

35. Rivera-Páez F, Labruna MB, Martins TF, Rodrígues B, Camargo-Mathias M. Amblyomma mixtum Koch, 1844 (Acari: Ixodidae): First record confirmation in Colombia using morphological and molecular analyses. Ticks Tick Borne Dis. 2016;5:842-8. https://doi.org/10.1016/j.ttbdis.2016.03.020

36. Quintero JC, Paternina LE, Uribe Y A, Muskus C, Hidalgo M, Gil J, et al. Eco-epidemiological analysis of rickettsial seropositivity in rural areas of Colombia: A multilevel approach. PLoS Negl Trop Dis. 2017;18:1-19. https://doi.org/10.1371/journal.pntd.0005892

37. Quintero JC, Mignone J, Osorio L, Cienfuegos-Gallet AV, Rojas AC. Housing conditions linked to tick (Ixodida: Ixodidae) infestation in rural areas of Colombia: A potential risk for rickettsial transmission. J Med Entomol. 2020;(X):1-11. https://doi.org/10.1093/jme/tjaa159

38. Miranda J, Máttar S. Molecular detection of Rickettsia bellii and Rickettsia sp. strain colombianensi in ticks from Córdoba, Colombia. Ticks Tick Borne Dis. 2014;5:208-12. https://doi.org/10.1016/j.ttbdis.2013.10.008

39. Londoño A, Díaz FJ, Valbuena G, Gazi M, Labruna MB, Hidalgo M, et al. Infection of Amblyomma ovale by Rickettsia sp. strain Atlantic rainforest, Colombia. Ticks Tick Borne Dis. 2014;5:672-5. https://doi.org/10.1016/j.ttbdis.2014.04.018

40. Cotes-Perdomo A, Santodomingo A, Castro LR. Hemogregarine and rickettsial infection in ticks of toads from northeastern Colombia. Int J Parasitol Parasites Wildl. 2018;7:237-42. https://doi.org/10.1016/j.ijppaw.2018.06.003

41. Santodomingo A, Sierra-Orozco K, Cotes-Perdomo A, Castro LR. Molecular detection of Rickettsia spp., Anaplasma platys and Theileria equi in ticks collected from horses in Tayrona National Park, Colombia. Exp Appl Acarol. 2019;77:411-23.

https://doi.org/10.1007/s10493-019-00354-8 